European journal of American studies

Special Issue: Spectacle and Spectatorship in American Culture

\title{
New Studies of Spectacle and Spectatorship in the
} United States: An Introduction

\section{Andrew M. Fearnley}

\section{(2) OpenEdition}

\section{Journals}

Electronic version

URL: https://journals.openedition.org/ejas/15359

DOI: $10.4000 /$ ejas. 15359

ISSN: 1991-9336

Publisher

European Association for American Studies

Electronic reference

Andrew M. Fearnley, "New Studies of Spectacle and Spectatorship in the United States: An Introduction", European journal of American studies [Online], 14-4 | 2019, Online since 11 December 2019, connection on 08 July 2021. URL: http://journals.openedition.org/ejas/15359 ; DOI: https:// doi.org/10.4000/ejas.15359

This text was automatically generated on 8 July 2021 .

Creative Commons License 


\title{
New Studies of Spectacle and Spectatorship in the United States: An Introduction
}

\author{
Andrew M. Fearnley
}

1 Over the last two decades, scholars from across several fields and periods have taken a renewed interest in spectacle and spectatorship. The trend has been evident among those working on the United States, where it has gathered pace in recent years, and led to a burst of new and innovative studies. This special issue, which took shape at a workshop held at the University of Manchester in 2017, convened to discuss these currents, now attempts to draw some of them together for American Studies scholars and those working on the history and culture of the US.

2 The study of spectacle has of course long been established among scholars of theatre and film, and art historians, given shape and force by Guy Debord's polemical Society of the Spectacle (1967), which presented "a society of images" as a new species of political power and social organization. What is notable about this subject's recent ascent is its widening scope, its embrace by literary scholars, and, more cautiously, by some historians and political scientists, and, especially given Debord's dismissal of that tradition of "sociology which began, first in the United States," its place within some discussions of the US. This impulse, admittedly a modest and uneven one among all Americanists, has nevertheless been perceptible in at least three bodies of scholarship, including recent studies of US politics, urban life, and racial subjugation.

3 While earlier academic discussions of spectacle understood it as an instance in which the popular will was enfeebled, recent studies of US political culture have invested "citizen spectators" with agency. ${ }^{1}$ To call an early American a spectator, the art historian Wendy Bellion argued in her study of eighteenth-century Philadelphia, was to suggest "an individual moved by or motivated to action by looking," with the spectacles created by paintings or scientific inventions being crucial to "citizen formation." Beyond galleries and salons, many antebellum Americans encountered spectacle at abolitionist meetings, through petitions and at plebeian demonstrations, which, as the 
literary scholar Jennifer Greiman has shown, "instituted forms of association and belonging that implicated spectators in what they watched," just as the political scientist Jeffrey Edward Green insists that in the highly mediated transactions of contemporary US politics, "spectatorship is inscribed in the very nature of political action itself." 3 Scholars of cities, especially, though not only, American ones, have long found value in a language of spectacle and spectatorship, and, since the 1990s, have coined several concepts-"slum spectacle," "urban spectatorship"-to describe the new cultural perspectives and experiences that these communities brought forth. ${ }^{4}$ One sign that urban scholars continue to find this language useful lies in its periodic updating, its application to discussions of postindustrial cities, and its adoption by those strains of contemporary architecture that create "urban spectacle" through upscale development. ${ }^{5}$ Interest in these concepts, though, has flourished most clearly in recent years among scholars of race, who have used spectacle-to mean, as Debord intended, "not a collection of images, but a social relation among people, mediated by images"-as a framework through which to interrogate racialized violence, particularly lynching, offering, in studies by Jacqueline Goldsby, Amy Louise Wood, and Debbie Lelekis, fresh and sophisticated perspectives. ${ }^{6}$

4 It is these features-of broadening interest, and growing use in academic discussions of the US-that occasion this special issue of the European Journal of American Studies. Far from attempting a definitive survey of the subject, the issue seeks to showcase the ways in which some Americanists have recently taken up these themes, doing so from a number of disciplinary perspectives. By ranging across two centuries, from roughly the 1770 s to the 1970s, the six essays bring into view the differing intensities at which the themes of "spectacle" and "spectatorship" have been present in US social and political life. The issue affords us a platform, then, from which we can judge if, as one scholar has argued, it was the case that spectacle held "particular significance during the nineteenth century," and why that might have been so. ${ }^{7}$ It adds weight to those scholars who have tried to expand the frameworks of spectacle and spectatorship, exploring how these concepts worked at sites such as the racetrack, the beach, and in the counterculture's psychedelic periodicals. In their own way, each contributor explores the conjunction between spectacle and spectatorship. Is this relationship linear, or, as Amy Louise Wood and Andrew Hannon's essays indicate, recursive? Together they also help to make spectacle a less nebulous category of description and analysis, teasing out the mechanics and stages of its creation and mediation: the bodies lynched in Mississippi, and the photographs of them that, as another scholar has written, also "spectaculariz[ed] white supremacy"; the dusty racetracks of the antebellum South, and the lithographs they inspired, stoking and shaping a popular wish to participate; Santa Monica's Muscle Beach, where bodies pranced and performed, and the refraction of that space in Life magazine and Hollywood films. ${ }^{8}$

5 All of the contributors offer case studies that historicize specific dimensions of spectacle and spectatorship in the US. The first two essays track spectacle in the American South, firstly in the city of Charleston, South Carolina, where, as Wendy Bellion argues, a monument erected to the British statesman William Pitt the Elder in the late eighteenth century was tied to the economy of Atlantic slavery and its hinterland of power. Bellion examines how this spectacle was produced, and the forms of governance it buttressed, attending to the artistic decisions and the material environment in which the figure was placed for twenty-four years, and claiming for the public realm what middling and wealthy Americans during these years asserted when, 
for instance, they hung maps in their drawing rooms as "ornaments" to impress others. ${ }^{9}$ Three miles north of the Pitt statue, lay Charleston's Washington Course, one of the South's most prominent racetracks, and, as Natalie Zacek argues, a site at which antebellum southerners fashioned themselves "as spectators not merely of sport, but of spectacle itself." While the language of spectacle has featured prominently in academic studies of US sports-one thinks of Michael Oriard's characterization of college football's transformation as the creation of an "American spectacle"-Zacek argues that, in the South, the racetrack offered a "broader category of spectacle," an emergent and unique public setting where, as with Gilded Age New York, an impulse "to see and be seen" arose from new social and cultural configurations. ${ }^{10}$ To adapt C.A. Bayly's observation about modernity, being a spectator seems first to involve the recognition that you are one. ${ }^{11}$

What kinds of spectators were imagined and addressed by certain photographic and filmic traditions is the question that courses through the essays by Amy Louise Wood and Molly Geidel. Wood recovers the history of one gruesome photograph, of a lynching in Mississippi in 1937, through its publication in Life magazine, its reproduction in popular catalogues, and its role as muse within a 1986 artistic work, to show how different modes of display and curation can produce varied responses among spectators, some of whom are moved to action by what they see. Wood is drawn to the ways in which the historicity of lynching imagery is often erased (all lynching photographs being characterized as interchangeable, universal symbols), not always by the forces of oppression, and crafts a framework that attends to this imagery's dual temporality-as evidence of past crimes needing redress, and as prompts to reflect on present-day images of racial violence..$^{12}$ Development documentary films that US studios made between the 1940s and late 1960s similarly envisaged two types of temporally-arranged spectators-those in the developing world, whom they sought to instruct, and those in the US, mainly school children, whose support they coveted. While recent scholarship on television in the early Cold War years has revealed how some executives used the medium to cultivate certain types of political subjects, Geidel's essay carries us further, arguing that filmmakers and political advisors regarded spectatorship as integral to America's modernization project. Development films were not only projections of US power and ideals, though they were that, but an apparatus that engaged viewers, training them to become modern subjects, informed and yet in thrall to the perspective of the filmmaker. ${ }^{13}$ In presenting "the idea of development as spectatorship," Geidel offers us another way to think about the strategic uses of spectacle, as political scientist Michael Rogin has done, within the arsenal of America's post-modern empire. ${ }^{14}$

7 The geography and transmission of spectacle in the postwar US and Europe is the subject of Elsa Devienne's and Andrew Hannon's essays. While the "California Look" was, as Devienne shows, largely the creation of mid-century Hollywood studios, it arose from a more complex spectacle which had developed four decades earlier, on the beaches and shores of southern California. Only by examining these prior spaces as "sites of spectacle," Devienne argues, is it possible to appreciate how a set of practices bodily regimes and styles became woven into Los Angeles' social fabric. If, in the 1950s, film elevated this regional phenomenon into a major national trope, in subsequent years, as Hannon shows in his essay, it was mass circulation magazines that energized an international audience of radicals. ${ }^{15}$ Taking coverage of San Francisco's hippies in Life and Time magazines as examples of recuperation, or attempts to neutralize the 
radicalism of America's counterculture, Hannon shows how some London-based readers nevertheless read rebellion into those scornful stories. Some artists were inspired to set up $O Z$ magazine, groups such as the Hyde Park Diggers, and, in turn, to build a toolkit-of satirical writing, street theatre, communes, and activism-that claimed spectacle for the avant-garde and for activists. Through his archival research, Hannon recovers a network of activists and artists, from San Francisco to London, who took up ideas theorized in Paris, and used them to turn spectacle from being a source of distraction into inspiring acts of engagement and social critique.

Several themes span the issue, though two are conspicuous and interrelated. The first concerns the variety of spectators that commentators and producers engaged, a function of a general move to recover a plurality of spectacles against the singular formation conjured by Debord. Bellion notes the "divergent audiences" that gazed at Pitt's statue, and its sculptor's awareness of "the knowledgeable spectator," attentive to his work's detail and allegory, while Geidel refers to the "sophisticated spectators" whom, by the early 1960s, some directors of development films addressed in more playful ways. This attention to varied spectator positions is also a tributary to the role that spectacle has played in US racial formations, in creating and maintaining boundaries between white and black. Here Pitt's statue is described as a "spectacle of whiteness," paid for from the proceeds of Atlantic slavery; Los Angeles beaches, and popular treatments of the "California Look," manufactured a "white spectacle," by restricting or, in the case of Hollywood portrayals, erasing the bodies of Hawaiians, Latinos, and African Americans. Lynching photographs were not only representations but also instruments of violence, and by showing them as the ur-imagery of US racial oppression Wood's essay implicitly makes clear the need to examine the other frequencies at which spectacle has served racial divisions-the southern police commissioners keen to have whites see their "dogs work" on civil rights activists, as well as the few images of Jim Crow signs, which, one scholar argues, "weren't spectacular or exceptional enough." 16 What correspondence these histories have to spectacle's role in buttressing contemporary US regimes of terror and domination also warrants further examination. ${ }^{17}$

9 We should not exaggerate the recent interest that Americanists have shown in these concepts, which, in some quarters, remain a shadowy presence, and certainly not a "stock phrase" of all fields..$^{18}$ Indeed, despite its blaring place in earlier critiques of consumerism, spectacle has been muted within recent studies of US capitalism, as it remains in this issue, mentioned only briefly, or as a facet of a clutch of recent studies. ${ }^{19}$ In fact spectacle only really continues to function as a tool for thinking about advanced capitalism in neighboring fields, such as media and film studies, a fact no doubt related to Debord's downgrading, here and more broadly, to historical actor (for instance, in Hannon's article) rather than interlocutor. ${ }^{20}$ Yet scholars of the US have shown a persistent interest in spectacle and spectatorship, and in some quarters there has been a blossoming of attention to such concepts, which, in contrast to earlier, have started to leach into new fields and subjects. The six essays gathered in this issue, alongside the works cited in this introduction, suggest that there remains much to be learned from renewed application, adaptation, and testing of such concepts and approaches. 


\section{NOTES}

1. Popular accounts tend to maintain the older usage; see Chris Hedges, Empire of Illusion: The End of Literacy and the Triumph of Spectacle (New York: Nation Books, 2010).

2. Wendy Bellion, Citizen Spectator: Art, Illusion, and Visual Perception in Early National America (Chapel Hill: University of North Carolina Press, 2011), 20.

3. Jennifer Greiman, Democracy's Spectacle: Sovereignty and Public Life in Antebellum American Writing (Philadelphia: Temple University Press, 2010), 21; Jeffrey Edward Green, The Eyes of the People: Democracy in an Age of Spectatorship (New York: Oxford University Press, 2010), 3. See also Amy Hughes, Spectacles of Reform: Theater and Activism in Nineteenth-Century America (Ann Arbor: University of Michigan Press, 2012).

4. The concepts are drawn from Keith Gandal, The Virtues of the Vicious: Jacob Riis, Stephen Crane and the Spectacle of the Slum (New York: Oxford University Press, 1997) and the US-based historian of London, Judith Walkowitz, City of Dreadful Delight: Narratives of Sexual Danger in Late-Victorian London (Chicago: University of Chicago Press, 1992). Related accounts include Dana Brand, The Spectator and the City in Nineteenth-Century American Literature (New York: Cambridge University Press, 1991); Vanessa Schwartz, Spectacular Realities: Early Mass Culture in Fin-de-siècle Paris (Berkeley: University of California Press, 1999); Tom Gunning, "From the Kaleidoscope to the X-Ray: Urban Spectatorship, Poe, Benjamin, and Traffic in Souls (1913)," Wide Angle 19 (October 1997): 25-61.

5. Eric Gordon writes about "possessive spectatorship" in The Urban Spectator: American Concept-Cities from Kodak to Google (Hanover, NH: Dartmouth College Press, 2010). Costas Spirou and Dennis Judd, Building the City of Spectacle: Mayor Richard M. Daley and the Remaking of Chicago (Ithaca, NY: Cornell University Press, 2016); Tom Dyckhoff, The Age of Spectacle: Adventures in Architecture and the 21st-Century City (London: Random House, 2017); Leslie Kern and Gerda Wekerle, "Gendered Spaces of Redevelopment: Gendered Politics of City Building," in Gender in an Urban World, ed. Judith N. DeSena and Ray Hutchison (Bingley, UK: Emerald JAI Press, 2008), 233-62.

6. Guy Debord, Society of the Spectacle (1967; Black \& Red, 1984), $\$ 4$ (my emphasis); Jacqueline Goldsby, A Spectacular Secret: Lynching in American Life and Literature (Chicago: University of Chicago Press, 2006); Amy Louise Wood, Lynching and Spectacle: Witnessing Racial Violence in America, 1890-1940 (Chapel Hill: University of North Carolina Press, 2011); Debbie Lelekis, American Literature, Lynching, and the Spectator in the Crowd (Lanham, MD: Lexington Books, 2015). The degree to which lynching is now approached through the framework of spectacle can also be glimpsed in Leigh Raiford, Imprisoned in a Luminous Glare: Photography and the African American Freedom Struggle (Chapel Hill: University of North Carolina Press, 2011), chap. 1.

7. Hughes, Spectacles of Reform, 6 .

8. The quotation about white supremacy is from Raiford, Imprisoned in a Luminous Glare, 39.

9. Martin Brückner, "The Spectacle of Maps in British America, 1750-1800," in Early American Cartographies, ed. Martin Brückner (Chapel Hill: University of North Carolina Press, 2011), 389-441.

10. Michael Oriard, Reading Football: How the Popular Press Created an American Spectacle (Chapel Hill: University of North Carolina Press, 1993); Oriard, King Football: Sport and Spectacle in the Golden Age of Radio \& Newsreels, Movies \& Magazines, The Weekly \& The Daily Press (Chapel Hill: University of North Carolina Press, 2001); see also, Jennifer Guiliano, Indian Spectacle: College Mascots and the 
Anxiety of Modern America (New Brunswick, NJ: Rutgers University Press, 2015); Michael J. Socolow, Six Minutes in Berlin: Broadcast Spectacle and Rowing Gold at the Nazi Olympics (Urbana: University of Illinois Press, 2016). The quotation about the Gilded Age is in Maureen Montgomery, Displaying Women: Spectacles of Leisure in Edith Wharton's New York (New York: Routledge, 1998).

11. C.A. Bayly, The Birth of the Modern World, 1780-1914 (Oxford: Blackwell, 2004), 10.

12. On the way in which spectacle produces the "outlawing of history" see Guy Debord, "Comments on the Society of the Spectacle," Feb.-April 1988, http://www.ubu.com/ papers/debord_comments.html (viewed August 21, 2019)

13. Anna McCarthy, The Citizen Machine: Governing by Television in 1950s America (New York: New York University Press, 2010).

14. Michael Rogin, "Make My Day! Spectacle as Amnesia in Imperial Politics," Representations 29 (Winter 1990): 99-123. More broadly on the role that popular culture has played in using spectacle to naturalize US empire, see Mark Storey, 'Ben-Hur and the Spectacle of Empire,' Studies in American Fiction 42 (Spring, 2015): 85-102.

15. Europe's Situationist International learned of the Watts rebellion, in Los Angeles, through similar channels; see Frances Stracey, "Consuming the Spectacle: The Watts Revolt and a New Proletariat," in As Radical as Reality Itself: Essays on Marxism and Art for the 21st Century, ed. Matthew Beaumont, et al. (Bern: Peter Lang, 2007), 251-282.

16. Martin Berger, Seeing through Race: A Reinterpretation of Civil Rights Photography (Berkeley: University of California Press, 2011), 51; Elizabeth Abel, Signs of the Times: The Visual Politics of Jim Crow (Berkeley: University of California Press, 2010), 106.

17. A suggestive starting point is Amy Lyford and Carol Payne, "Photojournalism, Mass Media and the Politics of Spectacle," Visual Resources 212 (2005): 119-129.

18. Jonathan Crary, "Spectacle, Attention, Counter-Memory," October 50 (Autumn 1989): 96-107, quotation at 96 .

19. These terms feature hardly at all in the important volume American Capitalism: New Histories, eds. Sven Beckert and Christine Desan (New York: Columbia University Press, 2018). Recent such studies that use this language, to varying degrees, include Peter Knight, Reading the Market: Genres of Financial Capitalism in Gilded Age America (Baltimore: Johns Hopkins University Press, 2016), esp. 90-91; Lukas Rieppel, Assembling the Dinosaur: Fossil Hunters, Tycoons, and the Making of Spectacle (Cambridge, MA: Harvard University Press, 2019).

20. Among the most sophisticated such treatments remains that by communications scholar Susan G. Davis, Spectacular Nature: Corporate Culture and the Sea World Experience (Berkeley: University of California Press, 1997); a more recent account in film studies is John Rhodes, Spectacle of Property: The House in American Film (Minneapolis: University of Minnesota Press, 2017).

\section{AUTHOR}

\section{ANDREW M. FEARNLEY}

Andrew Fearnley is an historian of the twentieth-century United States at the University of Manchester. His primary research interest concerns the history of racial thought in the modern 
US, though his essays have also addressed the concept of periodization in African American history, fundraising within the Black Panther Party, and sports spectatorship in the late twentieth-century US. His co-edited collection, Race Capital? Harlem as Setting and Symbol (2019) was published by Columbia University Press. 